\title{
The question of estimating the efficiency of investment costs in the agro-industrial complex
}

\author{
A.Yu. Gusev* \\ Ryazan State Agrotechnological University Named after P. A. Kostychev, 390048, Ryazan, Russia
}

\begin{abstract}
The assessment of the effectiveness of investments in the sectors of the national economy and, first of all, in agriculture, in most countries of the world is very relevant for all participants in the investment process. The key point of effectiveness is the payback periods of investments. The shorter they are, all other things being equal, the higher the efficiency of investment costs is. In a market economy, changes in the value of banknotes are constantly occurring over time, therefore, in the current conditions, it is advisable to assess the cost and effectiveness of investment costs, considering the time period (time lag). This method will allow to adjust the assessment and cost of financial investments in an investment project, considering the time factor. Agricultural development priorities should be focused on technical and technological modernization and innovation. One of the key directions for the development of the investment process in the country is the renewal of the material and technical base of the agricultural sector.
\end{abstract}

\section{Introduction}

The problems of assessing the effectiveness of investments in the sectors of the economy and, first of all, in agriculture, in most countries of the world are very relevant for all participants in the investment process. The need for systematic and constant investment in the agricultural sector of the national economy is confirmed by conclusions and scientific results of many scientists. For example, a number of experts in the field of agriculture argue that the growth of labor productivity in agriculture and reduction of current production costs are possible only on the basis of expanding the scale of investment activity, especially in the active part of fixed assets [1]. As studies of foreign scientists show [2], the lack of capital is a constraining factor in the growth of agricultural production efficiency in the country, which means that the increase in investment costs in the agricultural sector of the economy contributes to the growth of production and profitability of the agricultural sector. Studies by a number of native scientists prove the need for a sustainable increase in the efficiency of the agro-industrial complex through the investment component [3-7]. The value and role of investments, their objective assessment and role in the development of the state economy are presented in the study [8], which confirms that large-scale investments carried out over a long period can have a high prolonged economic effect, give stability to

\footnotetext{
${ }^{*}$ Corresponding author: ay.gusev@mail.ru
} 
agriculture, stimulate the growth of agricultural production. Russian scientists also believe [9] that at the present stage of economic development of the country and its agricultural sector, in particular, investment costs in agriculture are a key factor in the growth of labor productivity, which determines the incentive for further progressive development of the industry. Our scientific research also confirms the conclusions and views of both native and foreign scientists that investments in the agricultural sector of the economy for the vast majority of countries, including Russia, are key factors in the sustainable development of agriculture, the growth of its economic efficiency, guarantees of food independence and security [10-14]. Researchers agree with this position [15], who, using the example of the Republic of Uzbekistan, argue that food independence is largely determined by the level of modernization and intensification of agricultural production. Thus, investment costs in priority areas of development of the agricultural sector of the economy are designed to ensure such independence. Nevertheless, understanding the need for investment development in relation to the conditions of Russia, scientists believe an important role today is given to state support for investment and innovation for the agriculture, its successful development in the present and future [16]. The problem of investment performance is especially acute for investors who are interested in a stable and high return on investment costs, and an increase in their profitability. An important point of efficiency is the payback period of investments. The shorter it is, the higher the efficiency is, therefore, one of the key goals that the investor strives for is to reduce the payback period of investments. In a narrower sense of the word, the concept of investment can be identified as capital investments that are aimed at acquiring new ones, as well as the reconstruction and modernization of existing non-current assets. Today a very urgent task for Russia is precisely this direction of the investment vector of the development of the national economy, since in most industries, fixed assets are more than half worn out. One of the priority directions for the development of the investment process in the country is the renewal of the material and technical base of agriculture using the mechanism of leasing transactions [17]. The advantages of leasing as a tool for material and technical support have been proven in works of other researchers [18]. The investment potential of countries and regions is distinguished by a number of qualitative and quantitative characteristics, among which indicators of the size of investment in the sectors of the national economy and agriculture, in particular, are important. Another important parameter of efficiency is the rate of return on investment resources. At one time, during the Soviet era, the assessment of the effectiveness of capital investments was made according to the methodology of Academician T.S. Khachaturov, in which the author proposed to measure the effect of capital investments with costs spent on them. To assess the efficiency of capital investments, there was also an indicator of marginal (minimum efficiency), or "coefficient of national economic efficiency" with which the calculated indicator was compared. In addition, this normative parameter was differentiated by sectors of the economy (industry, agriculture, construction, transport, etc.). If it was equal to or higher than the normative one, the project was recognized as effective. Currently, the assessment of the effectiveness of investments is based on the algorithm for calculating this indicator, but one should remember an important feature of the market economy, namely, it is necessary to consider the change in the value of investment resources in space and time. The market economy is a living organism in which the value of banknotes changes over time. Therefore, if, based on these calculations, the time value of monetary equivalents is not considered, it is possible to recognize an investment project as effective, and after a certain period of time this project may be unsuitable for implementation, due to the changed conditions at financial, foreign exchange markets, economic conditions in the investing country. 


\section{Materials and methods}

To solve this problem, it is proposed to evaluate the cost and effectiveness of investment projects, and therefore investment costs, considering the time period (time lag). This method will allow to adjust the assessment and cost of financial investments in an investment project considering the time period, and as a result, the change of the purchasing power of banknotes. In this case, analysts and investors will be able to draw objective conclusions about the effectiveness or inexpediency of investments. It is also important to predict the course of the investment situation for the future, then it will be possible to avoid or level out the risks of investors associated with investment resources. An important parameter for assessing the effectiveness of investments is the rate of return, i.e. the amount of profit (income) on investment resources. Along with this indicator, after the implementation of the investment project, it is necessary to determine the level of its profitability, comparing the profit (income) received from the sold products (works, services), created on the basis of new equipment, technologies, with the current production costs spent on its production. The reliability and correct assessment of the effect of the invested financial resources, considering changes in the market situation and the time lag in the process of making investments, will allow to bring them closer to the realities, as well as more reliably assess the effectiveness of investments. When determining the efficiency of investment resources, the main problem arises and that is the problem of objective assessment of the level of inflation in the country and linking this parameter to the calculation of indicators of the cost of investment resources. For example, Table 1 presents the official data on the key refinancing rate determined by the Central Bank of the Russian Federation and the inflation rate in the country for the period of 2015-2020.

Table 1. Data on the inflation rate and the key refinancing rate of the Central Bank of the Russian Federation for 2015-2020

\begin{tabular}{|l|l|l|l|l|l|l|}
\hline Indicators & 2015 & 2016 & 2017 & 2018 & 2019 & 2020 \\
\hline Key refinancing rate, \% & 11.0 & 10.0 & 7.75 & 7.75 & 6.25 & 4.25 \\
\hline Average annual inflation rate, \% & 12.91 & 5.38 & 2.52 & 4.27 & 3.05 & 4.91 \\
\hline
\end{tabular}

As follows from the data presented, the indicators of the key rate and the inflation rate differ significantly. It should be remembered that the cost of credit and investment resources in the Russian Federation is tied to the level of the key rate, therefore, one should focus on this indicator. Moreover, it is closer to the essence of the ongoing and existing trends in the economy, so the calculation should be carried out with a focus on this indicator. For an example of calculating and adjusting the investment resources of Ryazan region and the agricultural sector in space and time, Table 2 provides a comparative assessment and calculation of the current value of investments at a specific point in time. To evaluate and compare the result, to confirm or refute assumptions, the calculation is carried out according to two parameters of efficiency assessment, namely, the key refinancing rate and the inflation rate.

The average annual inflation rate, since it is calculated according to a limited range of parameters, calculated as a whole for the country and its acceptance into the calculation of investment efficiency indicators, should be approached with a high degree of caution, since this indicator is very underestimated and cannot reflect the essence of the value of investment costs and an objective assessment of the change in their value over time. As evidenced by the presented calculation options for assessing the investment costs, the most acceptable in modern conditions is their assessment at the key refinancing rate, which more deeply and carefully evaluates the economic processes taking place in the country, and therefore more correctly estimates the cost of investment resources at a specific point in time. In this case, when calculating at the key refinancing rate of the Central Bank of the 
Russian Federation and calculating according to the average annual inflation rate, the discrepancies in the assessment of the investment costs are very significant. For example, for the region as a whole, the deviation in the assessment of the investment costs in monetary terms in 2017 was 2,607.5 million rubles, in 2018 it was 1,586.5 million rubles, in 2019 it was 1,563.2 million rubles. The deviation in the agricultural sector was respectively 298.5 million rubles in 2017, 290.4 million rubles in 2018, 292.3 million rubles in 2019 or in relative terms, both in the region as a whole and in the agricultural sector, the level of error (adjustment) by year was, respectively, $5.7 \%, 3.8 \%$ and $3.4 \%$. Investments differ from current investments in that the period of their development lasts for several years, and sometimes even decades, therefore, when assessing the cost of investment resources in time, this specific feature should also be considered. In the example under study, the investment process continued in 2020, so the value of investments already made earlier should be adjusted for inflationary processes in the economy for this period, including for 2020. Only in this case it is possible to arrive at an objective assessment of the current value investment costs. Thus, by adjusting the efficiency of investment costs over a long investment period, it is possible to estimate the loss of the value of investments in space and time. This provision is confirmed by the calculation presented in analytical Table 3 , where in 2020 the processes of adjusting investments in time continue in order to reach the objective parameter of their payback. The adjustment process should continue until the investment project is completed, when a final assessment of the investment cost effectiveness is required. In calculating the indicators in Table 3, for comparison, an algorithm for adjusting investment costs was applied considering two parameters, namely, the key refinancing rate of the Central Bank of the Russian Federation and the average annual inflation rate in the country. For a more reliable assessment of the result, if investors focus on calculating efficiency in terms of inflation, it should be recommended to use regional parameters of the inflation rate in calculating investment cost efficiency indicators, since they more reliably reflect the state and degree of development of the economy of a particular region where investments are made.

Table 2. Assessment of the effectiveness of investment costs, considering the time period of their implementation

\begin{tabular}{|l|l|l|l|}
\hline Indicators & 2017 & 2018 & 2019 \\
\hline Fixed capital investments, total, mln. rubles & $49,858.2$ & $45,589.5$ & $48,847.3$ \\
\hline including agriculture & $5,707.2$ & $8,345.1$ & $9,140.7$ \\
\hline Average annual inflation rate, \% & 2.52 & 4.27 & 3.05 \\
\hline Key refinancing rate, \% & 7.75 & 7.75 & 6.25 \\
\hline $\begin{array}{l}\text { Deviation of the key refinancing rate from the average } \\
\text { annual inflation rate, \% }\end{array}$ & +5.23 & +3.48 & +3.20 \\
\hline $\begin{array}{l}\text { Real value of investments at the end of the year, adjusted for } \\
\text { the average annual inflation rate for the whole region, mln. } \\
\text { rubles }\end{array}$ & $48,601.7$ & $43,642.8$ & $47,357.5$ \\
\hline including agriculture & $5,563.4$ & $7,988.8$ & $8,861.9$ \\
\hline $\begin{array}{l}\text { Real value of investments at the end of the year adjusted for } \\
\text { the key refinancing rate, mln. rubles }\end{array}$ & $45,994.2$ & $42,056.3$ & $45,794.3$ \\
\hline including agriculture, mln. rubles & $5,264.9$ & $7,698.4$ & $8,569.5$ \\
\hline $\begin{array}{l}\text { Deviation in the change in the cost of investment resources } \\
\text { in the region as a whole (calculation according to the key } \\
\text { rate minus calculation according to the average annual } \\
\text { inflation rate), mln. rubles }\end{array}$ & $\begin{array}{l}45,994.2- \\
48,601.7= \\
-2,607.5\end{array}$ & $\begin{array}{l}42,056.3- \\
43,642.8= \\
-1,586.5\end{array}$ & $\begin{array}{l}45,794.3- \\
47,357.5=- \\
1,563.2\end{array}$ \\
\hline $\begin{array}{l}\text { including agriculture, mln. rubles } \\
\text { f, }\end{array}$ & $\begin{array}{l}5,264.9- \\
5,563.4=-\end{array}$ & $\begin{array}{l}7,698.4- \\
7,988.8=-\end{array}$ & $\begin{array}{l}8,569.5- \\
8,861.9=- \\
298.5\end{array}$ \\
\hline
\end{tabular}


Table 3. Dynamics of changes in investment costs, considering the timing of the investment and the duration of the investment process

\begin{tabular}{|l|l|l|l|}
\hline Indicators & 2018 & 2019 & 2020 \\
\hline $\begin{array}{l}\text { The real cost of investment at the beginning of the year, adjusted } \\
\text { for the average annual inflation rate in the region as a whole, } \\
\text { mln. rubles }\end{array}$ & $48,601.7$ & $43,642.8$ & $47,357.5$ \\
\hline including agriculture & $5,563.4$ & $7,988.8$ & $8,861.9$ \\
\hline $\begin{array}{l}\text { Real value of investments at the beginning of the year adjusted } \\
\text { for the key refinancing rate, mln. rubles }\end{array}$ & $45,994.2$ & $42,056.3$ & $45,794.3$ \\
\hline including agriculture, mln. rubles & $5,264.9$ & $7,698.4$ & $8,569.5$ \\
\hline Average annual inflation rate, \% & 4.27 & 3.05 & 4.91 \\
\hline Key rate, \% & 7.75 & 6.25 & 4.25 \\
\hline $\begin{array}{l}\text { The real cost of investment at the end of the year, adjusted for } \\
\text { the average annual inflation rate in the region as a whole, mln. } \\
\text { rubles }\end{array}$ & $46,526.4$ & $42,311.7$ & $45,032.2$ \\
\hline including agriculture & $5,325.8$ & $7,745.1$ & $8,426.8$ \\
\hline $\begin{array}{l}\text { Real value of investments at the end of the year adjusted for the } \\
\text { key refinancing rate, mln. rubles }\end{array}$ & $42,429.6$ & $39,427.8$ & $43,848.0$ \\
\hline including agriculture & $4,856.8$ & $7,217.3$ & $8,205.3$ \\
\hline
\end{tabular}

The presented table demonstrates the assessment and calculation of the loss of the value of investments over time in the process of capital expenditures, as well as considering changes in the indicators of the average annual inflation rate and the key refinancing rate of the Central Bank of the Russian Federation by years. A more detailed calculation of the change in the value of investment costs and their losses due to inflation on an accrual basis over time is presented by the calculation algorithm in Table 4.

Table 4. The loss of the value of investment costs due to inflationary processes on an accrual basis over time

\begin{tabular}{|c|c|c|c|c|c|}
\hline Indicators & 2017 & 2018 & 2019 & 2020 & $\begin{array}{l}\text { Total } \\
\text { inflationary } \\
\text { investment } \\
\text { losses for the } \\
\text { entire } \\
\text { development } \\
\text { period }\end{array}$ \\
\hline $\begin{array}{l}\text { According to the valuation } \\
\text { method, considering the } \\
\text { average annual inflation rate (at } \\
\text { the end of the year), mln. rubles }\end{array}$ & $1,256.5$ & $\begin{array}{c}4,022.0 \\
(1,946.7+ \\
2,075.3)\end{array}$ & \begin{tabular}{|c|}
$2,820.9$ \\
$(1,489.8+$ \\
$1,331.1)$
\end{tabular} & $2,325.3$ & $10,424.7$ \\
\hline including agriculture & 143.8 & $\begin{array}{c}593.9 \\
(356.3+ \\
237.6) \\
\end{array}$ & $\begin{array}{c}522.5 \\
(278.8+ \\
243.7) \\
\end{array}$ & 435.1 & $1,695.3$ \\
\hline $\begin{array}{l}\text { Using the valuation method, } \\
\text { considering the key refinancing } \\
\text { rate (at the end of the year), } \\
\text { mln. rubles }\end{array}$ & $3,864.0$ & $\begin{array}{c}7,248.8 \\
(3,864.0+ \\
3,564.6)\end{array}$ & \begin{tabular}{|c|}
$5,747.1$ \\
$(3,090.9+$ \\
$2,656.2)$
\end{tabular} & $\begin{array}{c}4,999.3 \\
(3,053.0+ \\
1,946.30)\end{array}$ & $16,110.4$ \\
\hline including agriculture & 442.3 & $\begin{array}{c}850.4 \\
(442.3+ \\
408.1) \\
\end{array}$ & \begin{tabular}{|c|}
$1,127.8$ \\
$(647.7+$ \\
$481.1)$ \\
\end{tabular} & $\begin{array}{c}935.4 \\
(571.2+ \\
364.2) \\
\end{array}$ & $3,355.9$ \\
\hline
\end{tabular}

Thus, the total inflationary losses can be determined quite reliably based on the calculations presented. In this case, comparative options are used to assess the loss of value, which makes it possible to determine that according to the option of calculating with a 
reference to the average annual inflation rate inflationary investment losses in the region for the entire period of the project development will amount to 10,424.7 million rubles, including those in the agriculture equal to 1,695.3. According to the valuation method, focused on the key refinancing rate, these values are 16,110.4 and 3,355.9 million rubles, respectively.

\section{Results and discussion}

The need to consider the level of inflationary processes in the economy of the state, and as a result, in the investment environment in any sector of the national economy (agriculture, industry, construction, etc.) makes it possible to adjust the already implemented or planned costs for the inflation rate. This will allow timely and additional investments in the required volume in a particular direction of investment activity. The proposed calculation algorithm allows predicting the financial result, reaching the programmed income or profit from an investment project. For example, the effectiveness of an investment project in agriculture will be considered and evaluated. This project has a definite size of investments and the level of their profitability, for a period of four years. The assessment is based on the current (without inflation adjustment) and the proposed methodology for assessing the effectiveness of investments focused on changing the market situation as for the cost of investment resources and considering the inflation rate in the country (Table 5). The efficiency (profitability) of the given investment project is accepted and planned by the investor at the level of $26 \%$.

When evaluating the efficiency of investments using the methodology without adjusting for inflation, an investment project with a programmed profitability level of $26 \%$ will require investments in the amount of 295.5 million rubles. This calculation is quite simple and does not consider inflationary processes in the country or the region. In order to achieve the programmed profitability at the level of $26 \%$, the efficiency (profitability) indicators of the investment project should be adjusted to obtain additional income from additional investments. In this case, these parameters were calculated both by years (investment periods) and by the project as a whole, considering two possible variants of the algorithm for calculating the level of profitability of current costs, adjusted for inflation. According to the algorithm focused on the average annual inflation rate, in order to reach the programmed level of profitability, the need for investment resources will amount to 306.2 million rubles or will be 10.7 million rubles more. According to the algorithm focused on the key refinancing rate, acceptable for a more reliable assessment of the effectiveness of investment costs, the need for investments is estimated at 314.71 million rubles, which is 19.21 million rubles more than without inflation adjustment and 8.51 million rubles more than when considering the inflation rate. When assessing the effectiveness of investments and the change in their value over time, an important place is given to the proposed adjustment coefficient of profitability, focused on the average annual inflation rate and the key refinancing rate, and used in both calculation algorithms. 
Table 5. Comparative assessment of the efficiency of investment projects, considering adjustment for investment losses due to inflationary processes in the national economy

\begin{tabular}{|c|c|c|c|c|c|}
\hline Indicators & 2017 & 2018 & 2019 & 2020 & $\begin{array}{l}\text { Total } \\
\text { (average) }\end{array}$ \\
\hline \multicolumn{6}{|c|}{ Algorithm without inflation adjustment } \\
\hline $\begin{array}{l}\text { Financial resources of the investment project, mln. } \\
\text { rubles }\end{array}$ & 85.5 & 63.4 & 72.1 & 74.5 & 295.5 \\
\hline $\begin{array}{l}\text { Programmed income (profit) from an investment } \\
\text { project }\end{array}$ & 22.2 & 16.5 & 18.7 & 19.4 & 76.8 \\
\hline $\begin{array}{l}\text { The level of profitability of the investment project, } \\
\%\end{array}$ & 26.0 & 26.0 & 26.0 & 26.0 & 26.0 \\
\hline \multicolumn{6}{|c|}{ Algorithm focused on the average annual inflation rate } \\
\hline $\begin{array}{l}\text { Financial resources of the investment project, mln. } \\
\text { rubles }\end{array}$ & 85.5 & 63.4 & 72.1 & 74.5 & 295.5 \\
\hline $\begin{array}{l}\text { Programmed income (profit) from an investment } \\
\text { project }\end{array}$ & 22.2 & 16.5 & 18.7 & 19.4 & 76.8 \\
\hline Inflation rate, $\%$ & 2.52 & 4.27 & 3.05 & 4.91 & - \\
\hline $\begin{array}{l}\text { Additional financial resources are required, } \\
\text { adjusted for inflation, to reach the programmed } \\
\text { profit and profitability, mln. rubles }\end{array}$ & 2.15 & 2.70 & 2.19 & 3.66 & 10.70 \\
\hline Adjusted investment resources, mln. rubles & 87.65 & 66.10 & 74.29 & 78.16 & 306.2 \\
\hline Profitability adjustment factor & 0.975 & 0.959 & 0.970 & 0.953 & 0.965 \\
\hline $\begin{array}{l}\text { The level of profitability of the investment project } \\
\text { (adjusted for inflation expectations), \% }\end{array}$ & 25.36 & 24.93 & 25.23 & 24.78 & 25.09 \\
\hline $\begin{array}{l}\text { Programmed level of income, focused on the } 26 \% \\
\text { level of profitability of the investment project, mln. } \\
\text { rubles }\end{array}$ & 22.78 & 17.19 & 19.32 & 20.32 & 79.61 \\
\hline \multicolumn{6}{|c|}{ Algorithm focused on the key refinancing rate } \\
\hline $\begin{array}{l}\text { Financial resources of the investment project, mln. } \\
\text { rubles }\end{array}$ & 85.5 & 63.4 & 72.1 & 74.5 & 295.5 \\
\hline $\begin{array}{l}\text { Programmed income (profit) from an investment } \\
\text { project }\end{array}$ & 22.2 & 16.5 & 18.7 & 19.4 & 76.8 \\
\hline Key refinancing rate, $\%$ & 7.75 & 7.75 & 6.25 & 4.25 & - \\
\hline $\begin{array}{l}\text { Additional financial resources are required, } \\
\text { adjusted for inflation, to reach the programmed } \\
\text { profit and profitability, mln. rubles }\end{array}$ & 6.63 & 4.91 & 4.50 & 3.17 & 19.21 \\
\hline Adjusted investment resources, mln. rubles & 92.13 & 68.31 & 76.6 & 77.67 & 314.71 \\
\hline Profitability adjustment factor & 0.928 & 0.928 & 0.941 & 0.959 & 0.939 \\
\hline $\begin{array}{l}\text { The level of profitability of the investment project } \\
\text { (adjusted for inflation expectations), \% }\end{array}$ & 24.10 & 24.12 & 24.47 & 24.93 & 24.41 \\
\hline $\begin{array}{l}\text { Programmed level of income, focused on the } 26 \% \\
\text { level of profitability of the investment project, mln. } \\
\text { rubles }\end{array}$ & 23.95 & 17.76 & 19.91 & 20.19 & 81.81 \\
\hline
\end{tabular}

\section{Conclusion}

Thus, the proposed methodology for assessing the effectiveness of investment costs makes it possible to assess inflationary expectations for the future and to predict additional investment resources required for uninterrupted support of the investment process. Moreover, it allows avoiding the annual adjustment of investment costs during the entire investment time lag, as it is done today, since it makes possible to assess risks, current inflationary processes, inflationary expectations in the future and at the same time 
determine and adjust the required size of investment resources, including those for the future, in order to implement an investment project successfully.

\section{References}

1. Masek, J., Novak, P. (2018). Overview of combine harvester and tractor structure on farms in the Czech Republic. Engineering for Rural Development, 17: 240-245.

2. Mosavi, S.H., Soltani, S., Khalilian, S. (2020). Coping with climate change in agriculture: Evidence from Hamadan-Bahar plain in Iran. Agricultural Water Management, 241: 106332.

3. Bakulina, G., Fedoskin, V., Pikushina, M., Kukhar, V., Kot, E. (2020). Factor analysis models in enterprise costs management. International Journal of Circuits, Systems and Signal Processing, 14: 232-240.

4. Makarova, O., Makarov, V., Gasparyan, S., Napris, Z., Shemyakin, A. (2020). E3S Web of Conferences, 175: 01003.

5. Konkina, V.S., Martynushkin, A.B. (2020). Analysis of import substitution processes in the milk and dairy products market using cluster analysis. International Transaction Journal of Engineering, Management and Applied Sciences and Technologies, 11, 10: 11A10L.

6. Sandu, I.S., Chepik, D.A. (2014). Formation of an innovation system in the agricultural sector of the Russian economy: preconditions and problems. Bulletin of Orel SAU, 5 (50): 19-22.

7. Morozov, N.M. (2020). Econ. of Agr. of Russia, 2: 2-8.

8. Sinha, J.K. (2019). Influence of technologies on the growth rate of GDP from agriculture: A case study of sustaining economic growth of the agriculture sector in Bihar. Statistical Journal of the IAOS, 35(2): 277-287.

9. Semin, A., Truba, A. (2019). Technopark and agro-cluster structures as a business for the scientific and technological development of the agro-industrial complex. Agricultural Economics of Russia, 7: 2-7.

10. Gusev, A. (2020). Estimation of the efficiency of synthetic fertilizers in intensifying agricultural production. International Scientific and Practical Conference. Development of the Agroindustrial Complex in the Context of Robotization and Digitalization of Production in Russia and Abroad (DAIC 2020). E3S Web of Conferences, 222: 06013. DOI: https://doi.org/10.1051/e3sconf/202022206013

11. Metelkova, E., Demishkevich, G. and Gusev, A. (2019). State support for the production of cattle meat: the experience of countries with high levels of selfsufficiency. International Scientific and Practical Conference on Agrarian Economy in the Era of Globalization and Integration. IOP Conf. Series: Earth and Environmental Science, 274.

12. Gusev, A.Yu., Medelyaeva, Z.P., Sycheva, T.A. (2018). Agroindustrial complex in the system of foreign economic activity of the region. Bulletin of Voronezh State Agrarian University, 11, 4 (59): 175-182.

13. Gusev, A.Yu. (2020). Rating of Central Federal District by key parameters of economic development. Advances in Economics, Business and Management Research. Proceedings of the International Conference on Policies and Economics Measures for Agricultural Development (AgroDevEco 2020): 132-135. DOI: 10.2991/aebmr.k.200729.025

14. Gusev, A.Yu. (2020). Problems and prospects of technical and technological renovation of the regional agro-industrial complex. Published under license by IOP Publishing Ltd IOP Conference Series: Earth and Environmental Science, Volume 699 , Development of the agro-industrial complex in the context of robotization and 
digitalization of production in Russia and abroad 15-16 October 2020, Yekaterinburg City, Russian Federation DAICRA 2020 IOP Conf. Series: Earth and Environmental Science 699 (2021) 012011 IOP Publishing doi:10.1088/1755-1315/699/1/012011

15. Yuldashev, N.K., Nabokov, V.I., Nekrasov, K.V. and Tursunov, B.O. (2020). Modernization and intensification of agriculture in the republic of Uzbekistan. Development of the Agroindustrial Complex in the Context of Robotization and Digitalization of Production in Russia and Abroad" (DAIC 2020). E3S Web of Conferences, 222: 06033. https://doi.org/10.1051/e3sconf/202022206033

16. Galikeev, R. (2021). Investment and innovation strategy as a factor in increasing the competitiveness of the region. Russian Agricultural Economics, 1: 25-29.

17. Gusev, A.Yu. (2012). Modern problems of leasing relations in the agricultural sector of the economy. International agricultural journal, 4: 23-24.

18. Polyanskaya, N., Polyanskaya, N., Naydanova, E., Kolesnik, A., Kolesnik, I., Bryanskaya, O. (2021). Agroleasing as a tool for material and technical support in the agrarian sector. Russian Agricultural Economics, 1: 30-40. 